\title{
Chemotherapy Does Not Influence Intestinal Amino Acid Uptake in Children
}

\author{
BARBARA A. DE KONING, SOPHIE R. VAN DER SCHOOR, DARCOS L. WATTIMENA, PETER C. DE LAAT, \\ ROB PIETERS, AND JOHANNES B. VAN GOUDOEVER
}

\author{
Departments of Pediatric Oncology/Hematology [B.A.K., R.P.], Neonatology [S.R.S., J.B.G.], and Medium Care [P.C.L.], Erasmus \\ MC-Sophia Children's Hospital, 3015GJ Rotterdam, the Netherlands; Department of Internal Medicine [D.L.W.], Laboratory of Mass \\ Spectrometry, Erasmus Medical Center, 3000CB Rotterdam, the Netherlands
}

\begin{abstract}
Chemotherapy will frequently induce intestinal damage (mucositis). Enteral nutrition is then often withheld for fear of impaired intestinal absorption as shown in animal models. There is no clinical evidence, however, that absorption is indeed compromised during chemotherapy-induced mucositis. The aim of this study was to evaluate systemic availability of dietary amino acids (leucine) during chemotherapy-induced mucositis. We studied eight childhood cancer patients (age 1.5-16 y) on $2 \mathrm{~d}$, i.e. the day before chemotherapy and 3-5 d after. Chemotherapy-induced oral mucositis and diarrhea were scored on a World Health Organization toxicity scale. Stable isotope tracers were used to measure first-pass splanchnic leucine uptake and whole-body leucine kinetics. Patients showed increased mucositis and/or diarrhea toxicity scores $(p<0.0001)$ after chemotherapy. Systemic availability of enterally administered leucine was not significantly affected by chemotherapy (before $60 \%$, after $90 \%, p=0.46$ ). Interestingly, five patients already showed a negative leucine balance before chemotherapy. In conclusion, most children receiving chemotherapy are already catabolic before start of a new cycle of chemotherapy. Amino acid transport as measured by leucine uptake in the intestine is not affected by chemotherapyinduced mucositis. (Pediatr Res 62: 195-199, 2007)
\end{abstract}

$\mathrm{C}$ hemotherapy may severely damage the intestinal mucosa, resulting in a condition referred to as mucositis $(1,2)$. Mucositis is characterized by major morphologic changes of the intestinal epithelium, such as epithelial flattening, villus atrophy, and specific down-regulation of the enterocytespecific gene expression that is crucial for degradation and absorption of nutrients (3-5). It is unknown how this condition effects digestion and absorption of enteral nutrition.

Normally, the intestine itself metabolizes a substantial part of the nutrients absorbed from the intestinal lumen in first-pass splanchnic uptake $(6,7)$. Animal and human studies have shown that $20-80 \%$ of dietary essential amino acids are used within the intestine $(8-10)$. The more nutrients are used by the small intestine, the fewer essential amino acids are systemically available for whole-body energy metabolism and protein synthesis. It is unknown whether chemotherapy-induced mucositis affects first-pass splanchnic amino acid uptake. We hypothesized, first, that chemotherapy-induced mucositis will

Received October 10, 2006; accepted March 7, 2007

Correspondence: Johannes B. van Goudoever, M.D., Ph.D., Neonatology, Erasmus MC-Sophia Children's Hospital, Sp 3432, Dr. Molewaterplein 60, P.O. Box 2060, 3000 CB Rotterdam, The Netherlands; e-mail: j.vangoudoever@erasmusmc.nl

Supported by a grant from Numico Research BV, Wageningen, the Netherlands. lead to lower nutrient uptake by the intestine and, second, that it will lead to a higher intestinal utilization rate due to mucosal regeneration. The combined result would be a lower systemic availability of dietary amino acids.

To test these hypotheses we determined first-pass splanchnic uptake of dietary leucine, an essential amino acid, in pediatric patients before and after receiving mucotoxic chemotherapy.

\section{METHODS}

Subjects. The ethics review board of the Erasmus MC-Sophia Children's Hospital approved the study. Informed consent was obtained from parents and patients, as appropriate. Eligible subjects were patients aged between 1 and $18 \mathrm{y}$, admitted for a cycle of chemotherapy in their drug regimen with known high risk of severe intestinal side effects. Patients diagnosed with acute myeloid leukemia (AML) and B cell-non-Hodgkin lymphoma (B-NHL) fulfilled these criteria already at diagnosis. Acute lymphoid leukemia (ALL) patients were eligible if they had developed mucositis during a previous chemotherapy cycle. Exclusion criteria were cow's milk allergy and abdominal radiotherapy.

Protocol. Each subject was studied on 2 d, i.e. the day before start of chemotherapy and 3-5 d after chemotherapy. The study protocol was similar on these days, as illustrated in Figure 1. The degree of oral mucositis and diarrhea were scored according to the World Health Organization (WHO) criteria (Table 1).

All patients had a central venous catheter already in place, which was used to infuse stable isotopes. Blood samples were collected by capillary blood puncture. Breath samples of patients younger than $5 \mathrm{y}$ were collected as described before (11). Older patients were asked to exhale into a Vacutainer through a straw. After a 4-h fast, patients who were capable of drinking received a formula diet (Tentrini, Nutricia, Zoetermeer, The Netherlands), every hour for $5 \mathrm{~h}$. Others were continuously fed this formula through a nasogastric tube. Nutrient intake was similar on both study days. Three different stable isotopes were infused. First, a primed, continuous 2-h i.v. infusion $[4.7 \mu \mathrm{mol} / \mathrm{kg}$ and $4.7 \mu \mathrm{mol} /(\mathrm{kg} / \mathrm{h})]$ of $\left[{ }^{13} \mathrm{C}\right]$ sodium bicarbonate $(99.0$ mol\% ${ }^{13} \mathrm{C}$; Cambridge Isotopes, Woburn, MA) dissolved in sterile saline was administered at a constant rate. This was immediately followed by a primed, continuous i.v. infusion $[11.3 \mu \mathrm{mol} / \mathrm{kg}$ prime and $11.3 \mu \mathrm{mol} /(\mathrm{kg} / \mathrm{h})]$ of $1{ }^{13} \mathrm{C}$ leucine $\left(98.0 \mathrm{~mol} \%{ }^{13} \mathrm{C}\right.$; Cambridge Isotopes) and an intragastric infusion $[11.0 \mu \mathrm{mol} / \mathrm{kg}$ and $11 \mu \mathrm{mol} /(\mathrm{kg} / \mathrm{h})]$ of ${ }^{2} \mathrm{H}_{3}$ leucine $\left(98.0 \mathrm{~mol} \%{ }_{2} \mathrm{H}^{3} ; \mathrm{Cam}-\right.$ bridge Isotopes), both for $3 \mathrm{~h}$.

Baseline blood and breath samples were collected just before start of tracer infusion. Breath samples were also taken every 15 min during the last $45 \mathrm{~min}$ of sodium bicarbonate infusion and during the last hour of leucine infusion. Two blood samples were collected during the last $15 \mathrm{~min}$ of leucine infusion (T 285, $300 \mathrm{~min}$.). The heparinized blood was directly put on melting ice, centrifuged, and stored at $-80^{\circ} \mathrm{C}$ until further analysis.

Abbreviations: KICA, 2-ketoisocaproic acid; LRP, leucine release from protein breakdown (measure for protein breakdown); MPE, mole percent excess; NOLD, non-oxidative leucine disposal (measure for protein synthesis) 


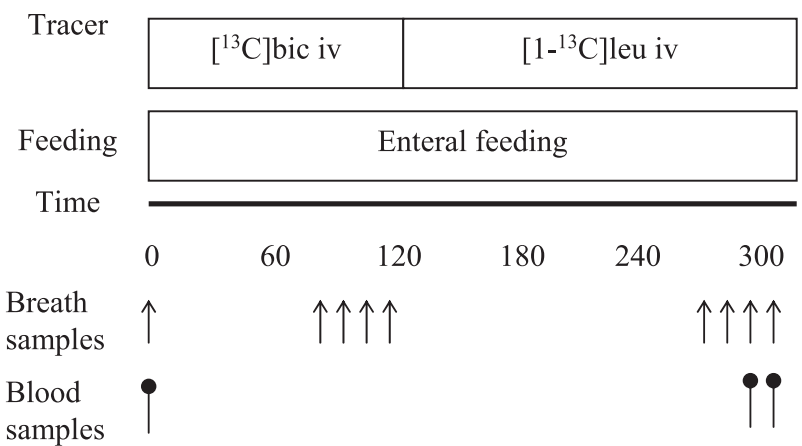

Figure 1. Schematic overview of study day before and after chemotherapy. $\left[{ }^{13} \mathrm{C}\right]$ bic, $\left[{ }^{13} \mathrm{C}\right]$ sodium bicarbonate; $\left[1-{ }^{13} \mathrm{C}\right]$ leu, $\left[1-{ }^{13} \mathrm{C}\right]$ leucine.

Table 1. WHO grading scale of oral mucositis and diarrhea

\begin{tabular}{lll}
\hline & \multicolumn{1}{c}{ Oral mucositis } & \multicolumn{1}{c}{ Diarrhea } \\
\hline 0 & None & None \\
1 & Soreness/erythema & Transient, $<2 \mathrm{~d}$ \\
2 & Erythema, ulcers, can eat solids & Tolerable, but $>2 \mathrm{~d}$ \\
3 & Ulcers require liquid diet only & Intolerable, requires therapy \\
4 & Oral alimentation impossible & Hemorrhagic dehydration \\
\hline
\end{tabular}

Calculations. The assessment of amino acid kinetics by stable isotope technique is based on the following model (12):

Turnover or Flux $(\mathrm{Q})=$ Intake + Breakdown $=$ Synthesis + Oxidation

Amino acids enter a metabolic pool via diet (Intake) and protein breakdown (Breakdown), and are withdrawn from this pool by protein synthesis (Synthesis) or amino acid oxidation (Oxidation). During steady state, tracer enters and leaves the pool at equal rate. This process of replacement or renewal of a given substance is referred to as turnover or flux.

All calculations used were previously described by van der Schoor et al. (13).

Equation 1 is the above-mentioned model modified for leucine: leucine entering the pool equals leucine leaving the pool. Leucine enters the pool via intake (I) and through leucine release from protein breakdown (LRP) and leaves the pool via NOLD, a measure of protein synthesis rate, and through leucine oxidation $(\mathrm{OX})$.

$$
\mathrm{Q}=\mathrm{I}+\mathrm{LRP}=\mathrm{NOLD}+\mathrm{OX}
$$

$\mathrm{Q}$, flux of leucine tracer $[\mu \mathrm{mol} /(\mathrm{kg} / \mathrm{h})]$; I, LRP, NOLD, and OX $[\mu \mathrm{mol} /$ $(\mathrm{kg} / \mathrm{h})]$.

The rate of leucine flux was calculated by measuring the dilution of its intracellular representation KICA at steady state as modified for stable isotope tracers $(14,15)$.

Equation 2a calculates the leucine flux of the i.v. tracer.

$$
\mathrm{Qiv}=\mathrm{IL} \times[(\mathrm{Ei} / \mathrm{Ep}) / \mathrm{Ep}]
$$

Qiv, flux of intravenous leucine tracer $\left[1-{ }^{13} \mathrm{C}\right]$ leucine $[\mu \mathrm{mol} /(\mathrm{kg} / \mathrm{h})] ; \mathrm{i}_{\mathrm{L}}$, leucine infusion rate $[\mu \mathrm{mol} /(\mathrm{kg} / \mathrm{h})]$; Ei and $\mathrm{Ep}$ are the enrichments in mole percent excess (MPE) of $\left[1-{ }^{13} \mathrm{C}\right]$ leucine in the leucine infusate and $\left[1-{ }^{13} \mathrm{C}\right]$ KICA in plasma during steady state, respectively.

Equation $2 \mathrm{~b}$ calculates the leucine flux of the intragastric tracer.

$$
\text { Qig }=\mathrm{IL} \times[(\mathrm{Ei} / \mathrm{Ep}) / \mathrm{Ep}]
$$

Qig, flux of intragastric leucine tracer $\left[{ }^{2} \mathrm{H}_{3}\right]$ leucine $[\mu \mathrm{mol} /(\mathrm{kg} / \mathrm{h})] ; \mathrm{i}_{\mathrm{L}}$, leucine infusion rate $[\mu \mathrm{mol} /(\mathrm{kg} / \mathrm{h})]$; Ei and Ep are the enrichments (MPE) of $\left[{ }^{2} \mathrm{H}_{3}\right]$ leucine in the leucine infusate and $\left[{ }^{2} \mathrm{H}_{3}\right] \mathrm{KICA}$ in plasma at steady state, respectively.

After determining both i.v. and intragastric tracer flux, first-pass splanchnic uptake can be calculated.

Equation 3 calculates first-pass up-take fraction (\%).

$$
\text { First Pass Uptake }=[(\mathrm{Qig}-\mathrm{Qiv}) / \mathrm{Qig}]
$$

Equation 4 calculates the absolute first-pass leucine uptake in $\mu \mathrm{mol} /(\mathrm{kg} / \mathrm{h})$.

$$
\text { Absolute First Pass Uptake }=[(\text { Qig }- \text { Qiv }) / \text { Qig }] \times \text { I }
$$

I, enteral leucine intake $(\mu \mathrm{mol} /(\mathrm{kg} / \mathrm{h}))$.

Equation 5 calculates the fraction of leucine oxidized.

$$
\text { Fraction of leucine oxidized }=[\mathrm{IEL} \times \mathrm{iB}] /[\mathrm{IEB} \times \mathrm{iL}]
$$

$\mathrm{IE}_{\mathrm{L}}$ and $\mathrm{IE}_{\mathrm{B}},{ }^{13} \mathrm{CO}_{2}$ enrichment at steady state during i.v. $\left[1-{ }^{13} \mathrm{C}\right]$ leucine and $\left[{ }^{13} \mathrm{C}\right]$ sodium bicarbonate infusion, respectively; $\mathrm{i}_{\mathrm{L}}$ and $\mathrm{i}_{\mathrm{B}}$, infusion rate $[\mu \mathrm{mol} /(\mathrm{kg} / \mathrm{h})]$ of leucine and bicarbonate, respectively, as described previously (16)

Equation 6 is calculated by multiplying the outcome of Equation 5 with the flux of the i.v. leucine tracer as calculated in Equation 2a (although this does not take first-pass oxidation into account).

$$
\text { Whole-Body Leucine Oxidation }=[\mathrm{Eq} 5 .] \times[\mathrm{Qiv}]
$$

Equation 7 calculates leucine balance.

$$
\begin{aligned}
\text { Balance }= & \text { NOLD }- \text { LRP }(\text { Leucine Used for Synthesis } \\
& - \text { Leucine Used for Breakdown })
\end{aligned}
$$

Leucine balance $[\mu \mathrm{mol} /(\mathrm{kg} / \mathrm{h})]$.

Analytical methods. ${ }^{13} \mathrm{CO}_{2}$ enrichment in the breath samples was measured on an isotope ratio mass spectrometer (ABCA; Europa Scientific, Van Loenen Instruments, Leiden, the Netherlands) (17). Plasma enrichment of $\left[1-{ }^{13} \mathrm{C}\right]$ and $\left[{ }^{2} \mathrm{H}_{3}\right]$ KICA in small aliquots of plasma was determined by gas chromatography/ mass spectrometry (18).

Statistics. All data are expressed in median $\left(25^{\text {th }}\right.$ percentile $-75^{\text {th }}$ percentile) values obtained from the breath or blood samples taken at the end of each tracer infusion. The distribution of the differences in direction and magnitude between the two related values (before and after chemotherapy) was compared by Wilcoxon signed-ranks tests. A value of $p<0.05$ was considered statistically significant.

\begin{tabular}{|c|c|c|c|c|c|c|c|c|}
\hline & 1 & 2 & 3 & 4 & 5 & 6 & 7 & 8 \\
\hline Patient & 1.8 & 1.7 & 2.4 & 11.9 & 13.1 & 6.7 & 7.0 & 15.8 \\
\hline Diagnosis & ALL & AML & AML & AML & AML & $\mathrm{BNH}$ & $\mathrm{BNH}$ & $\mathrm{BNH}$ \\
\hline Cycle & MD-MTX & MAE & $\mathrm{ADE}$ & $\mathrm{ADE}$ & $\mathrm{ADE}$ & COPADM & COPADM & COPADM \\
\hline Before chemotherapy & 1 & 0 & 0 & 0 & 0 & 0 & 1 & 0 \\
\hline After chemotherapy & 2 & 0 & 0 & 2 & 0 & 2 & 3 & 1 \\
\hline \multicolumn{9}{|l|}{ Diarrhea (WHO grade) } \\
\hline
\end{tabular}

\section{RESULTS}

Patients, treatment, and toxicity. Eight patients participated in the study; age at diagnosis and type of chemotherapy are listed in Table 2. Seven patients were measured both before and after chemotherapy. In one patient, baseline measurements are lacking for logistic reasons. All patients showed good clinical health, with no or only moderate signs of diarrhea

Table 2. Patient characteristics

Median mucositis and diarrhea scores are shown.

Cycle, chemotherapy cycle; ALL, acute lymphoid leukemia; AML, acute myeloid leukemia; B-NHL, B-non-Hodgkin lymphoma; MD-MTX, medium dose methotrexate; MAE, ara-C, mitoxantrone, and etoposide; $\mathrm{ADE}$, ara-C, daunorubicin, and etoposide; COPADM, vincristine, cyclophosphamide, doxorubicin, and high-dose MTX. 
or oral mucositis on the first study day (Table 2). Following chemotherapy, however, the clinical condition of seven patients had deteriorated. They showed increased mucositis and/or diarrhea WHO-toxicity scores $(p<0.0001)$. Two patients demonstrated weight loss and two other patients suffered from severe abdominal pain. Four patients already received tube feeding before the study days, and were given formula through this tube; the other four received a normal diet (although characterized by a reduced intake). Table 3 shows the individual intake of all patients on both study days.

Leucine kinetics. Table 4 shows the ${ }^{13} \mathrm{CO}_{2}$ enrichment expressed in MPE of breath-samples collected during steady

Table 3. Calorie $(\mathrm{kcal} / \mathrm{kg} / \mathrm{h})$ and protein $(\mathrm{mg} / \mathrm{kg} / \mathrm{h})$ intake during study day 1 and 2

\begin{tabular}{cccccc}
\hline & \multicolumn{2}{c}{ Study day 1} & & \multicolumn{2}{c}{ Study day 2} \\
\cline { 2 - 3 } \cline { 5 - 6 } Patient & Calorie & Protein & & Calorie & Protein \\
\hline 1 & 1.5 & 60 & & 1.5 & 60 \\
2 & 2.5 & 100 & & 2.5 & 100 \\
3 & & & & 4.6 & 184 \\
4 & 1.1 & 44 & & 1.4 & 56 \\
5 & 0.4 & 16 & & 0.4 & 16 \\
6 & 1.3 & 52 & & 1.4 & 56 \\
7 & 1.5 & 60 & & 1.8 & 72 \\
8 & 1.5 & 60 & & 1.7 & 68 \\
\hline
\end{tabular}

Table 4. $\mathrm{MPE} \mathrm{CO}_{2}$ and leucine plasma isotopic enrichments (\%) before and after chemotherapy

\begin{tabular}{|c|c|c|c|c|}
\hline \multirow[b]{2}{*}{ Patient } & \multicolumn{2}{|c|}{ Breath samples } & \multicolumn{2}{|c|}{ Serum samples } \\
\hline & $\begin{array}{c}{ }^{13} \mathrm{CO}_{2} \\
\text { enrichment } \\
\text { (MPE) } \\
\text { (after }\left[{ }^{13} \mathrm{C}\right] \\
\text { bicarbonate i.v.) }\end{array}$ & $\begin{array}{c}{ }^{13} \mathrm{CO}_{2} \\
\text { enrichment } \\
\quad(\mathrm{MPE}) \\
\text { (after }\left[{ }^{13} \mathrm{C}\right] \\
\text { leucine iv) }\end{array}$ & $\begin{array}{l}1-{ }^{13} \mathrm{C} \\
\text { KICA } \\
\text { (MPE) }\end{array}$ & $\begin{array}{c}{ }^{2} \mathrm{H}_{3} \\
\text { KICA } \\
\text { (MPE) }\end{array}$ \\
\hline \multicolumn{5}{|c|}{ Before chemotherapy } \\
\hline 1 & 0.0149 & 0.0138 & 3.59 & 2.03 \\
\hline 2 & 0.0240 & 0.0126 & 3.86 & 2.35 \\
\hline \multicolumn{5}{|l|}{3} \\
\hline 4 & 0.0260 & 0.0136 & 2.67 & 3.80 \\
\hline 5 & 0.0161 & 0.0145 & 2.65 & 1.30 \\
\hline 6 & 0.0221 & 0.0102 & 3.76 & 2.37 \\
\hline 7 & 0.0154 & 0.0882 & 6.81 & 3.22 \\
\hline 8 & 0.0326 & 0.0354 & 2.78 & 2.68 \\
\hline Median & 0.0161 & 0.0138 & 3.59 & 2.37 \\
\hline p25 & 0.0149 & 0.0123 & 2.67 & 2.03 \\
\hline p75 & 0.0240 & 0.0354 & 3.86 & 3.22 \\
\hline \multicolumn{5}{|c|}{ After chemotherapy } \\
\hline 1 & 0.0140 & 0.0160 & 2.97 & 3.20 \\
\hline 2 & 0.0109 & 0.0140 & 2.80 & 2.30 \\
\hline 3 & 0.0157 & 0.0139 & 2.54 & 5.36 \\
\hline 4 & 0.0351 & 0.0241 & 2.66 & 3.03 \\
\hline 5 & 0.0238 & 0.0235 & 3.68 & 1.65 \\
\hline 6 & 0.0224 & 0.0254 & 2.44 & 2.36 \\
\hline 7 & 0.0168 & 0.0165 & 4.61 & 3.15 \\
\hline 8 & 0.0371 & 0.0319 & 4.03 & 0.88 \\
\hline Median & 0.0196 & 0.0200 & 2.89 & 2.70 \\
\hline p25 & 0.0144 & 0.0145 & 2.57 & 1.81 \\
\hline p75 & 0.0323 & 0.0251 & 3.94 & 3.19 \\
\hline$p$ & 0.31 & 0.50 & 0.31 & 0.5 \\
\hline
\end{tabular}

Leu, leucine; $\mathrm{p} 25,25$ th percentile; $\mathrm{p} 75,75$ th percentile; $p$-value, Wilcoxon signed-rank test. state at the end of $\left[{ }^{13} \mathrm{C}\right]$ bicarbonate and leucine infusion. It also shows the enrichment of $\left[1-{ }^{13} \mathrm{C}\right]$ and $\left[{ }^{2} \mathrm{H}_{3}\right] \mathrm{KICA}$ (MPE) of serum collected at steady state. There are no significant differences in enrichment before and after chemotherapy.

The influence of chemotherapy-induced mucositis on firstpass splanchnic uptake and whole-body leucine kinetics is shown in Table 5. Before chemotherapy, there was a first-pass uptake of leucine as shown by the difference in turnover of the enterally and intravenously-administered tracer. Inasmuch as, before chemotherapy, a median of $40 \%$ of the dietary leucine was used in first pass or not absorbed, $60 \%$ was systemically available. Following chemotherapy, only $10 \%$ of the ingested leucine was used in first pass or not absorbed, so that $90 \%$ (median) was systemically available. However, this difference in intestinal utilization does not reach statistical significance. Both LRP (an indication of proteolysis) and leucine oxidation increased following chemotherapy. These differences did not reach statistical significance. NOLD (an indication of protein synthesis) was not affected by chemotherapy. Interestingly, five patients were found to be already in negative leucine balance (the equation NOLD - LRP has a negative result) before start of chemotherapy, indicating a catabolic leucine metabolism already before start of chemotherapy. This negative balance almost doubled following chemotherapy, although this difference was not statistically significant.

\section{DISCUSSION}

We studied leucine kinetics in children treated with chemotherapy as a means to evaluate the effect of chemotherapyinduced mucositis on intestinal amino acid absorption. Our data demonstrate that childhood cancer patients have at least a similar systemic availability of leucine just before receiving chemotherapy compared with healthy children (19). The systemic availability of leucine after chemotherapy during a period of mucositis did not change significantly, indicating that chemotherapy treatment does not affect amino acid transport in the intestine. On the other hand, in contrast to our hypothesis, it demonstrates that the intestinal mucosa does not use more amino acids during intestinal mucositis. These are unexpected results seeing that almost all patients showed a distinct increase in mucositis toxicity score. We would have expected that leucine availability from the intestinal lumen should be impaired. Surprisingly, too, we found almost all patients to be in negative leucine balance already before start of chemotherapy, representing catabolic metabolism. We would have expected that the children should be in an anabolic state at the start of a new cycle of chemotherapy. We conclude that in our study amino acid (leucine) absorption in children with cancer was not compromised during chemotherapyinduced mucositis.

However, our study may have had some limitations. First, it might have been underpowered to detect possible differences in the systemic availability of leucine: the study group was fairly small and the overall incidence of very severe mucositis (grade 3 or 4) was low. Second, the results on isotopic enrichment and consequent leucine kinetics showed great variability. This could be explained by the heterozygosis of 
Table 5. Leucine kinetics before and after chemotherapy

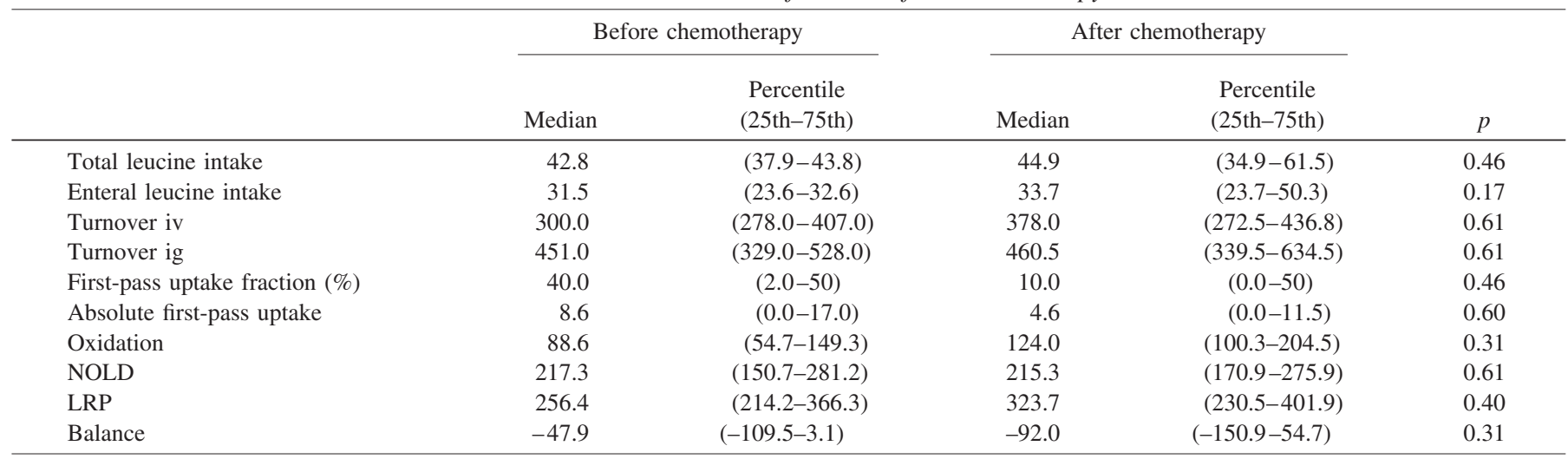

All values are expressed in $\mu \mathrm{mol} /(\mathrm{kg} / \mathrm{h}) . p$-Value, Wilcoxon signed-rank test; ig, intragastric; Oxidation, whole-body leucine oxidation; Balance, NOLD - LRP .

our study group. Patient characteristics showed a wide range in age, diagnosis, and treatment differences, which could cause variability in clinical condition. Third, we are well aware of the limitations of the described amino acid tracer studies. Intestinal absorption of only one essential amino acid was studied and not the entire cascade of digestion and absorption following a protein-containing meal. The transport of amino acids into the cytoplasm and through the basolateral membrane is facilitated by highly regulated transporter systems defined on the kinetic properties of the specific amino acid $(20,21)$. Transport of amino acids such as leucine in the intestinal brush border is regulated by the $\mathrm{L}$ and $\mathrm{B}^{0.8}$ system $(21,22)$ and is predominantly $\mathrm{Na}^{+}$-dependent $(22)$. In contrast, dietary components need to be digested before absorption by specific tightly regulated metabolic enzymes expressed in the brush border at the apical membrane of villus enterocytes.

From previous animal studies we know that different kinds of chemotherapy affect intestinal digestion and absorption processes dissimilar. Conflicting reports on protein digestion and amino acid absorption have been published. The expression of peptide transporter 1 (PepT1), involved in absorption of dipeptides and tripeptides formed after digestion of dietary proteins (23), appeared unchanged during 5 -flourouracil induced intestinal mucositis (24), whereas several amino acid transporters (neutral basic transporter and high-affinity glutamate transporter) showed decreased expression (24). On the other hand, glutamine supplementation seems to ameliorate chemotherapy induced toxicity (25-27). Although conflicting results are published, this could indicate that glutamine transport is not affected by chemotherapy. In vivo data available for glutamine transporters are lacking. Other macronutrients such as carbohydrates might be less well absorbed. Expression of sucrase isomaltase and lactase, two glycohydrolases responsible for degradation of complex carbohydrates into absorbable monosaccharide, is strongly down-regulated during mucositis $(5,28,29)$. Also, the monosaccharide transporters sodium glucose co-transporter 1 and glucose transporter 5, harbored at the apical enterocyte membrane and glucose transporter 2 at the basolateral membrane, are distinctly downregulated during mucositis (5). Although not clinically tested, these findings suggest that carbohydrates might be less properly absorbed during mucositis. Only a few data are available on the third macronutrient in the diet, lipids. Transport of fatty acid in the enterocyte by fatty acid binding protein seems to be less affected during severe mucositis (5).

So, in contrast to leucine absorption, we don't know whether the digestion of whole proteins in a regular meal is disturbed during a period of mucositis. An intrinsically labeled protein diet could be used to investigate whether digestion is impaired in children with mucositis following chemotherapy. Our data on leucine absorption and findings from previous animal studies (24) suggest a role for an elementary diet consisting of small peptides and free amino acids during mucotoxic treatment. Considering that most of our patients already showed catabolic state before start of chemotherapy, there is a definite need for the development of such elementary feeding. The more so since a major positive effect of proper nutrition in critically ill patients was demonstrated in recent years $(30-32)$.

In conclusion, we found that after mucotoxic chemotherapy in pediatric patients the intestinal mucosa is still capable of absorbing leucine efficiently. Additionally, most children receiving chemotherapy are already catabolic before start of a new cycle of chemotherapy. Therefore, all efforts should be directed at initiating enteral feeding even before start of chemotherapy to reduce catabolic state. Moreover, our data imply that this might be accomplished best by hydrolyzed formula.

\section{REFERENCES}

1. Sonis ST 2004 The pathobiology of mucositis. Nat Rev Cancer 4:277-284

2. Sonis ST, Elting LS, Keefe D, Peterson DE, Schubert M, Hauer-Jensen M, Bekele BN, Raber-Durlacher J, Donnelly JP, Rubenstein EB 2004 Perspectives on cancer therapy-induced mucosal injury: pathogenesis, measurement, epidemiology, and consequences for patients. Cancer 100:1995-2025

3. Hyams JS, Batrus CL, Grand RJ, Sallan SE 1982 Cancer chemotherapy-induced lactose malabsorption in children. Cancer 49:646-650

4. Naruhashi K, Nadai M, Nakao M, Suzuki N, Nabeshima T, Hasegawa T 2000 Changes in absorptive function of rat intestine injured by methotrexate. Clin Exp Pharmacol Physiol 27:980-986

5. Verburg M, Renes IB, Van Nispen DJ, Ferdinandusse S, Jorritsma M, Buller HA, Einerhand AW, Dekker J 2002 Specific responses in rat small intestinal epithelial mRNA expression and protein levels during chemotherapeutic damage and regeneration. J Histochem Cytochem 50:1525-1536

6. McNurlan MA, Garlick PJ 1980 Contribution of rat liver and gastrointestinal tract to whole-body protein synthesis in the rat. Biochem J 186:381-383

7. Lobley GE, Milne V, Lovie JM, Reeds PJ, Pennie K 1980 Whole body and tissue protein synthesis in cattle. Br J Nutr 43:491-502

8. Biolo G, Tessari P, Inchiostro S, Bruttomesso D, Fongher C, Sabadin L, Fratton MG, Valerio A, Tiengo A 1992 Leucine and phenylalanine kinetics during mixed meal ingestion: a multiple tracer approach. Am J Physiol 262:E455-E463 
9. van Goudoever JB, Stoll B, Henry JF, Burrin DG, Reeds PJ 2000 Adaptive regulation of intestinal lysine metabolism. Proc Natl Acad Sci U S A 97:11620 11625

10. Stoll B, Henry J, Reeds PJ, Yu H, Jahoor F, Burrin DG 1998 Catabolism dominates the first-pass intestinal metabolism of dietary essential amino acids in milk proteinfed piglets. J Nutr 128:606-614

11. Perman JA, Barr RG, Watkins JB 1978 Sucrose malabsorption in children: noninvasive diagnosis by interval breath hydrogen determination. J Pediatr 93: $17-22$

12. Waterlow JC 1967 Lysine turnover in man measured by intravenous infusion of L-[U-14C]lysine. Clin Sci 33:507-515

13. van der Schoor SR, Reeds PJ, Stellaard F, Wattimena JD, Sauer PJ, Buller HA, van Goudoever JB 2004 Lysine kinetics in preterm infants: the importance of enteral feeding. Gut 53:38-43

14. Steele R 1959 Influences of glucose loading and of injected insulin on hepatic glucose output. Ann N Y Acad Sci 82:420-430

15. Tserng KY, Kalhan SC 1983 Calculation of substrate turnover rate in stable isotope tracer studies. Am J Physiol 245:E308-E311

16. van Goudoever JB, Sulkers EJ, Kalhan SC, Sauer PJ 1993 Glucose metabolism in a term infant with transient hyperinsulinism and high carbohydrate intake. Eur J Pediatr 152:343-347

17. Zuijdgeest-van Leeuwen SD, van den Berg JW, Wattimena JL, van der Gaast A, Swart GR, Wilson JH, Dagnelie PC 2000 Lipolysis and lipid oxidation in weightlosing cancer patients and healthy subjects. Metabolism 49:931-936

18. Ford GC, Cheng KN, Halliday D 1985 Analysis of (1-13C)leucine and (13C)KIC in plasma by capillary gas chromatography/mass spectrometry in protein turnover studies. Biomed Mass Spectrom 12:432-436

19. Kien CL, Horswill CA, Zipf WB, McCoy KS, Denne SC 1999 Splanchnic uptake of leucine in healthy children and in children with cystic fibrosis. Pediatr Res 45: 680-683

20. Souba WW, Pacitti AJ 1992 How amino acids get into cells: mechanisms, models, menus, and mediators. JPEN J Parenter Enteral Nutr 16:569-578

21. Mailliard ME, Stevens BR, Mann GE 1995 Amino acid transport by small intestinal, hepatic, and pancreatic epithelia. Gastroenterology 108:888-910
22. Iannoli P, Miller JH, Wang HT, Bode B, Souba WW, Avissar NE, Sax HC 1999 Characterization of L-leucine transport system in brush border membranes from human and rabbit small intestine. Metabolism 48:1432-1436

23. Ganapathy V, Brandsch M, Leibach F 1994 Intestinal transport of amino acids and peptides. Raven, New York, pp 1773-1794

24. Tanaka H, Miyamoto KI, Morita K, Haga H, Segawa H, Shiraga T, Fujioka A, Kouda T, Taketani Y, Hisano S, Fukui Y, Kitagawa K, Takeda E 1998 Regulation of the PepT1 peptide transporter in the rat small intestine in response to 5-fluorouracil-induced injury. Gastroenterology 114:714-723

25. Jebb SA, Osborne RJ, Maughan TS, Mohideen N, Mack P, Mort D, Shelley MD, Elia M 1994 5-fluorouracil and folinic acid-induced mucositis: no effect of oral glutamine supplementation. Br J Cancer 70:732-735

26. Klimberg VS, Nwokedi E, Hutchins LF, Pappas AA, Lang NP, Broadwater JR, Read $\mathrm{RC}$, Westbrook KC Glutamine facilitates chemotherapy while reducing toxicity. JPEN J Parenter Enteral Nutr 1992;16:83S-87S

27. Blijlevens NM, Donnelly JP, Naber AH, Schattenberg AV, DePauw BE 2005 A randomised, double-blinded, placebo-controlled, pilot study of parenteral glutamine for allogeneic stem cell transplant patients. Support Care Cancer 13:790-796

28. Kralovanszky J, Prajda N 1985 Biochemical changes of intestinal epithelial cells induced by cytostatic agents in rats. Arch Toxicol Suppl 8:94-103

29. Taminiau JA, Gall DG, Hamilton JR 1980 Response of the rat small-intestine epithelium to methotrexate. Gut 21:486-492

30. Pollack MM, Ruttimann UE, Wiley JS 1985 Nutritional depletions in critically il children: associations with physiologic instability and increased quantity of care. JPEN J Parenter Enteral Nutr 9:309-313

31. den Broeder E, Lippens RJ, van't Hof MA Tolboom JJ, Sengers RC, van Staveren WA 2000 Association between the change in nutritional status in response to tube feeding and the occurrence of infections in children with a solid tumor. Pediatr Hematol Oncol 17:567-575

32. Barr J, Hecht M, Flavin KE, Khorana A, Gould MK 2004 Outcomes in critically ill patients before and after the implementation of an evidence-based nutritional management protocol. Chest 125:1446-1457

33. WHO 1979 WHO handbook for reporting results of cancer treatment. World Health Organization, Geneva, pp 13 